This is the accepted version of an article published in Journal of the Royal Asiatic Society Vol. 27 (4), 591-610 by Cambridge University Press. Available at: https://doi.org/10.1017/S1356186317000311 @ Richard David Williams

Accepted version downloaded from SOAS Research Online: http://eprints.soas.ac.uk/24618/

\title{
Songs between cities: listening to courtesans in colonial north India
}

\author{
Richard David Williams (University of Oxford)
}

\begin{abstract}
$\underline{\text { Abstract }}$
In the aftermath of 1857, urban spaces and cultural practices were transformed and contested. Regional royal capitals became nodes in a new colonial geography, and the earlier regimes that had built them were recast as decadent and corrupt societies. Demolitions and new infrastructures aside, this transformation was also felt at the level of manners, sexual mores, language politics, and the performing arts. This article explores this transformation with a focus on women's language, female singers and dancers, and the men who continued to value their literary and musical skills. While dancing girls and courtesans were degraded by policy-makers and vernacular journalists alike, their Urdu compositions continued to be circulated, published, and discussed. Collections of women's biographies and lyrics gesture to the importance of embodied practices in cultivating emotional positions. This cultivation was valued in late Mughal elite society, and continued to resonate for emotional communities of connoisseurs, listeners, and readers, even as they navigated the expectations and sensibilities of colonial society.
\end{abstract}

Over the nineteenth century, a variety of public women came under attack from both the colonial administration and Indian moralists and social reformers, who collapsed the distinctions between 'prostitutes', lower class singers, and elite courtesans. ${ }^{1}$ There were several impulses behind the social marginalisation of female artists, which has come to be termed the 'anti-nautch (dance) movement' ${ }^{2}$ In the early nineteenth century, the British began to discourage relationships with Indian women, but also lost interest in indigenous entertainments and cultural practices, including the patronage of dancing girls. ${ }^{3}$ Those sectors of the Indian middle class that fared well under the colonial economy also

\footnotetext{
${ }^{1}$ S. Waheed, 'Women of "Ill Repute": Ethics and Urdu Literature in Colonial India', Modern Asian Studies 48:4 (2014), pp. 986-1023.

2 'Nautch', a corruption of the Hindustani nāc (dance), refers to the dancer and her/his ensemble of musicians. See for example: A. Morcom, Illicit Worlds of Indian Dance: Cultures of Exclusion (London, 2013), pp. 32-41; S. Kidwai, 'The Singing Ladies find a voice', Seminar 540 (2004), pp. 48-54; L. du Perron, Hindi Poetry in a Musical Genre: Thumrī Lyrics (Abingdon, 2007), pp. 55-66; M.E. Walker, India's Kathak Dance in Historical Perspective (Farnham, 2014), pp. 89-98; S. Sachdeva, 'In Search of the Tawa'if in History: Courtesans, Nautch Girls and Celebrity Entertainers in India (1720s-1920s)', unpublished doctoral thesis, School of Oriental and African Studies, University of London (2008); P. Chakravorty, Bells of Change: Kathak Dance, Women and Modernity in India (Kolkata, 2008), pp. 43-7.

${ }^{3}$ S. Banerjee, Dangerous Outcast: The Prostitute in Nineteenth Century Bengal (Kolkata, 1998); E. Wald, 'From begums and bibis to abandoned females and idle women: sexual relationships, venereal disease and the redefinition of prostitution in early nineteenth-century India', Indian Economic and Social History Research 46:1 (2009), pp. 5-25.
} 
This is the accepted version of an article published in Journal of the Royal Asiatic Society Vol. 27 (4), 591-610 by Cambridge University Press. Available at: https://doi.org/10.1017/S1356186317000311 @ Richard David Williams

Accepted version downloaded from SOAS Research Online: http://eprints.soas.ac.uk/24618/

denounced female performers, calling them prostitutes and the root of social decay. ${ }^{4}$ These discursive attacks were compounded by political interventions, including the destruction of aristocratic patronage in cities like Delhi and Lucknow following the Uprising of 1857, and a series of legislative acts intended to regulate prostitution. These different campaigns against 'fallen women' had multiple implications: song genres were de-eroticised; instruments associated with the nautch became unpopular; women from 'respectable' families began to appear on the public stage; and many professional entertainers were forced into sex work in the absence of cultural patronage. ${ }^{5}$ Nonetheless, the culture of singing and dancing women survived in a much reduced form up to the present day: vitriolic campaigns against female performers were never entirely successful, as the same arguments and denouncements of elite patrons continued through to Independence and beyond. ${ }^{6}$

This article considers how female performing artists were understood in relation to language, literature, and urban culture in the late nineteenth century. In colonial north India, the cultural connotations of language were in dialogue with social changes: the language a courtesan spoke was not a given, but reflected the training and class of patron available to her. A focus on language - the social connotations of different registers, literary composition, and oral performance - sheds light on the strategies for survival available to public women in a changing moral climate, but also on the men who patronised and appreciated women artists. This focus allows us to consider courtesans as litterateurs, supplementing their usual characterisation as musicians and dancers, and takes into account the distinct advantages of being famed as a writer. As for the men: how did male patrons who were brought up to appreciate courtesans as the custodians of elite culture position themselves in a colonial society that was increasingly coloured by a new middle-class morality? Language was a tool for the social mobility of female performers, and was used to overcome a series of obstacles posed by colonialism.

\footnotetext{
${ }^{4}$ S. Joshi, Fractured Modernity: Making of a Middle Class in Colonial North India (New Delhi, 2001), pp. 63-65; M. J. Husain, Qadīm Lakhna'u kī āknhirī bāhār (New Delhi, 1981), p. 189; D. Bredi, 'Fallen Women: A Comparison of Rusva and Manto', The Annual of Urdu Studies 16 (2001), pp. 109-127.

${ }^{5}$ S. Chakraborty, 'To Sing or Not to Sing: In Search of One's Soul', Think India Quarterly 8:2 (2005), pp. 70-87; A. Weidman, 'Gender and the politics of voice: colonial modernity and classical music in South India', Cultural Anthropology 18:2 (2003), pp. 194-232; R.B. Qureshi, 'The Indian Sarangi: Sound of Affect, Site of Contest', Yearbook for Traditional Music 29 (1997), pp. 1-38.

${ }^{6}$ Walker, p. 95-8; S. Legg, 'Stimulation, Segreagation and Scandal: Geographies of Prostitution Regulation in British India, between Registration (1888) and Suppression (1923)', Modern Asian Studies 46:4 (2012), pp. 1459-1505; R. De, 'Husna Bai's Profession: Sex, Work and Freedom under the Indian Constitution (1950-1964)', unpublished paper presented at the Institute of Historical Research, 23rd May (2013).
} 
This is the accepted version of an article published in Journal of the Royal Asiatic Society Vol. 27 (4), 591-610 by Cambridge University Press. Available at: https://doi.org/10.1017/S1356186317000311 @ Richard David Williams

Accepted version downloaded from SOAS Research Online: http://eprints.soas.ac.uk/24618/

Insights from the history of emotions nuance these tensions and transitions in colonial society, especially when dealing with the archive of poets and their critics. In itself, poetic language can pose methodological problems for the cultural historian: when a literary genre (such as the Urdu ghazal) demands that emotions be articulated through prescribed aesthetic conventions, can a poem only be taken as evidence of a society's conceptual approach to emotions, or as an artefact of the poet's lived experience? ${ }^{7}$ The study of emotion demands looking beyond the words themselves to multisensorial and multimedial forms of interpretation and participation with the poetic 'text'. ${ }^{8}$ Experiencing a courtesan's poetry was not a matter of silent reading, but involved embodied voices, performance (recitation, singing, dancing), specific forms of sociability, material objects (relating to the salon or the printed page), and larger political considerations. The audience or consumer of the poem was not a passive recipient of these experiences, but responded through active listening (entailing gesture and response), and supplementary actions, perhaps including eating, drinking, and sex, all of which had transformative potential in terms of emotional impact. ${ }^{9}$ Both the multimodal delivery and the context-specific reception of poetry were theorized and mediated by associated knowledge systems relating to literary aesthetics, musicology, and conduct literature: an emotional community's tools for self-management and selfcultivation. ${ }^{10}$

Thinking of readers and audiences in terms of an emotional community, one 'tied together by fundamental assumptions, values, goals, feeling rules, and accepted modes of expression',11 has several implications. First, late Mughal readers were heavily invested in strategies of refinement, which prescribed their emotional engagement with courtesans through socially sanctioned forms of affection, friendship, and desire. Second, this coding of emotion influenced how men were placed in elite society, but also, as will be explored

\footnotetext{
${ }^{7}$ These two historiographical approaches are discussed in W. Andrews, 'Ottoman Love: Preface to a Theory of Emotional Ecology', in J. Liliequist, A History of Emotions, 1200-1800 (Abingdon, 2016), pp. 21-47. On courtesan poetry as autobiography, see Shweta Sachdeva Jha, 'Tawa'if as Poet and Patron: Rethinking Women's Self-Representation', in A. Malhotra and S. Lambert-Hurley, Speaking of the Self: Gender, Performance, and Autobiography in South Asia (Durham, 2015), pp. 141-164.

${ }^{8}$ M. Pernau and I. Rajamani, 'Emotional Translations: Conceptual History Beyond Language', History and Theory 55 (2016), pp. 46-65.

${ }^{9}$ This sense of the transformative is inspired by Reddy's notion of emotive statements, see W.M. Reddy, The Navigation of Feeling: A Framework for the History of Emotions (Cambridge, 2001), pp. 104-7. Ray hints at the significance of courtesans to the history of emotions in R.K. Ray, Exploring Emotional History: Gender, Mentality and Literature in the Indian Awakening (New Delhi, 2001), pp. 39-42.

${ }^{10}$ M. Pernau, 'From Morality to Psychology: Emotion Concepts in Urdu, 1870-1920', Contributions to the History of Concepts 11:1 (2016), pp. 38-57.

${ }^{11}$ B.H. Rosenwein, Emotional Communities in the Early Middle Ages (Ithaca, 2006), p. 24.
} 
This is the accepted version of an article published in Journal of the Royal Asiatic Society Vol. 27 (4), 591-610 by Cambridge University Press. Available at: https://doi.org/10.1017/S1356186317000311 @ Richard David Williams

Accepted version downloaded from SOAS Research Online: $\underline{\text { http://eprints.soas.ac.uk/24618/ }}$

below, had social and economic implications for performing women. Third, though it would be problematic to think of post-1857 India in terms of 'emotional regime' change, or the courtesan's salon as an 'emotional refuge' from a hegemonic emotional style informed by colonialism, ${ }^{12}$ it is helpful to consider how sensibilities cultivated in multiple emotional communities overlap in the experience of the colonial subject. It then becomes possible to view urban societies both as crucibles for new, mediated Anglophone mores and colonial subjectivities on the one hand, and as spaces for preserved forms of Mughal sociability and emotional practices on the other.

\section{Against the Nautch}

Under the Mughal Empire, music and dance were highly valued and different communities of professional performers specialised in repertoires for distinct contexts. Some women musicians only performed in the inner quarters of elite houses: domestic slaves (pātur), companions (ḱk awașs ), the wives of hereditary male musicians (mirasins) ${ }^{13}$, and other categories of singing-dancer (including gauharin) were reserved for the entertainment of aristocratic women and the private amusements of the lord of the household. ${ }^{14}$ When elite men hosted musical parties for their male companions they paid a different category of woman to perform, known most commonly as karicanī or kanjar, lülì, or $\underline{t} a w \bar{a}^{\prime} i f .{ }^{15}$ In theory, these women were not attached to one household, though some were retained by particular patrons. The most successful became significant patrons and political actors in their own right, but these were exceptional cases. ${ }^{16}$

The change in fortune of dancing girls - from a position of cultural authority, if not mainstream respectability, to one of marginalization and infamy - can be traced to colonial rule, when the British discontinued patronizing the nautch and increasingly defined dancing girls as prostitutes. As early as 1837, James Paton (1798-1847) published a bilingual pamphlet through the Baptist Mission Press, denouncing European and 'Native' patrons of

\footnotetext{
${ }^{12}$ I understand both terms as developed by Reddy (2001). Rosenwein cautions that this model tends towards a bipartite understanding of emotion, in terms of courtly regime and sentimentalism, both tied to processes of state formation. See Rosenwein, p. 23; Idem. 'Theories of Change in the History of Emotions', in Liliequist, pp. 7-20.

${ }^{13}$ Mirasins were distinguished from pātur by T. Williamson, The East India Vade-Mecum, ii (London, 1810).

${ }^{14}$ K.B. Schofield, 'The Courtesan Tale: Female Musicians and Dancers in Mughal Historical Chronicles, c.15561748', Gender \& History 24:1 (2012), pp. 150-171.

${ }^{15}$ The plural of the Perso-Arabic $t \bar{c}$ 'ifa, the term indicated a tribe, troop, or mobile company. On different categories of female performer see Schofield 2012; Morcom, pp. 61-86; Walker, p. 91. For regionally specific forms in Bengal, see Banerjee, pp. 21-31.

${ }^{16}$ E.g. Begam Samru and Munni Begam of Murshidabad.
} 
This is the accepted version of an article published in Journal of the Royal Asiatic Society Vol. 27 (4), 591-610 by Cambridge University Press. Available at: https://doi.org/10.1017/S1356186317000311 @ Richard David Williams

Accepted version downloaded from SOAS Research Online: http://eprints.soas.ac.uk/24618/

dance: 'An Exposition in English and Hindustani of the Evil Tendency of Naches, in corrupting the morals, and especially in supplying money for the further purchase of Innocent Female Children, for the wretched purpose of Prostitution! And an appeal to the respectable natives of India, and to all Christians by their influence and example to discountenance so great an evil.' 17 Paton was an educationist and reformer fixated on the elimination of vice. In 1837 he was based in Awadh as assistant to the Resident at Lucknow, William Sleeman, where he notoriously orchestrated the regulation and execution of Thugs. ${ }^{18}$ Paton saw dancing girls as the exploited victims of a pernicious industry that was spreading immorality and disease. He identified the $\underline{t} a w \bar{a}^{\prime} i f$ as a prostitute $(k a s b \hat{\imath})$ and the $n \bar{a} y i k a$ (the conductor of a performing troupe) as a procuress, who corrupted little girls and hired them out to sing for 'musical people' (rāga ke log). ${ }^{19}$

Despite this burst of anti-nautch fervour, it seems that most Europeans in India were not opposed to dancing girls until the 1860s, and even then the language used to describe them was mixed. ${ }^{20}$ Interest in indigenous entertainment slowly drained away, propelled by the increasing availability in cantonment towns of music and women from Britain.

However, morality was not always a consideration: even the politest circles of British society were comfortable attending a nautch hosted by Indian aristocrats. The Marchioness of Dufferin and Ava recorded one such entertainment in her diary in 1885:

'A Nautch in the Upper Hall,' says the programme! The old and blasé Anglo-Indian despised this one, and whispered something about music-halls; but as we are not blasé, it amused us very much... One of the women was very good-looking, and was heavily clothed from head to foot in velvet and gold, and a great scarf of green and gold; the other wore rather short pink petticoats, but when she did whirl round, one saw that she had on a regular suit of armour, cloth of gold down to the ankles. Nothing could be more strictly proper, and nothing could possibly be more languid and gentle and almost motionless than the dancing, if dancing it can be called. ${ }^{21}$

The newly-arrived Marchioness' reaction - a combination of curiosity and amusementcontrasts with that of the established Anglo-Indian, but even here the issue was a matter of

\footnotetext{
${ }^{17} \mathrm{~J}$. Paton, An Exposition in English and Hindustani of the Evil Tendency of Naches (Calcutta, 1837). Emphasis in the original.

${ }^{18}$ W.H. Carey, Oriental Christian Biography, containing biographical sketches of distinguished Christians who have lived and died in the East (Calcutta, 1850), iii, pp. 266-270. See R. Singha, "Providential" Circumstances: The Thuggee Campaign of the 1830s and Legal Innovation', Modern Asian Studies 27:1 (1993), pp. 83-146.

${ }_{19}$ Paton, pp. 21-3.

${ }^{20}$ Notable exceptions include Alexander Hamilton (1727) and Thomas Williamson (1810), who warned new British arrivals to Calcutta to stay clear of dancing girls. Banerjee, pp. 44-45

${ }^{21}$ Marchioness of Dufferin and Ava, Our Viceregal Life in India: Selections from my journal 1884-1888 (London, 1890), p. 67.
} 
This is the accepted version of an article published in Journal of the Royal Asiatic Society Vol. 27 (4), 591-610 by Cambridge University Press. Available at: https://doi.org/10.1017/S1356186317000311 @ Richard David Williams

Accepted version downloaded from SOAS Research Online: http://eprints.soas.ac.uk/24618/

taste rather than morality: the suggestion was that music-hall culture was preferable to a nautch, not that the nautch girl was a prostitute. Indeed, the Marchioness reassures her English readers that the entire spectacle was nothing but 'proper'. From other late travelogues, it is apparent that while the British gradually lost interest in the nautch, many of them did not see dancing girls as a social evil.

Nonetheless, colonial policies relating to the restructuring of cities and the regulation of military brothels had horrific consequences for public women. The Cantonment Acts of 1864 and 1889, supplemented by the Contagious Diseases Act of 1868 (repealed 1888), set up regulations for brothels visited by soldiers and other military personnel, including obligatory medical examinations and 'Lock Hospitals' designed to confine women with venereal diseases. 22 Although the Cantonment Act and Contagious Diseases Act were theoretically confined to brothels frequented by the army, they had a much wider impact. In Mysore the principles of the Acts were stretched to harass women accused of 'clandestine' prostitution: in some cases, women even committed suicide 'to escape the disgrace of being brought under the Lock Hospital Act'. ${ }^{23}$ The association of performing women with sexually-transmitted diseases fed into the rhetoric of the anti-nautch, as in Punjab where one reformist proclaimed: 'let those who are conscious of the evils of this custom shun dancing parties as contagious diseases.' ${ }^{24}$ In her study of post-Uprising Lucknow, Veena Oldenburg recorded the oral histories of courtesans, which suggested that women from elite salons (kothas) were forced to service soldiers. ${ }^{25}$ Following her account, other scholars have argued that these policies destroyed the prestige of high-status artists and forced them into sex work. ${ }^{26}$

However, this was not a universal outcome, and kotha culture was not eradicated entirely. Stephen Legg noted that these policies were difficult to implement and

\footnotetext{
22 Banerjee, pp. 59-69, 145-170; K. Ballhatchet, Race, Sex and Class under the Raj: Imperial Attitudes and Policies and their Critics, 1793-1905 (London, 1980), pp. 10-67; D.M. Peers, 'Privates off Parade: Regimenting Sexuality in the Nineteenth-Century Indian Empire', The International History Review 20:4 (1998), pp. 823-854. Lock Hospitals were introduced in India as early as 1797, see Wald 2009, pp. 14-15.

${ }^{23}$ Foreign Dept., General B, November 1872, 16-17 (National Archives of India).

${ }^{24}$ Lala Dharm Das Suri of Saharnpur, in Anon., Punjab Purity Association, Opinions on the Nautch Question (Lahore, 1894), p. 26.

${ }^{25}$ V. Oldenburg, 'Lifestyle as Resistance: The Case of the Courtesans of Lucknow, India', Feminist Studies 16:2 (1990), pp. 259-287, here 265; c.f. Wald, p. 18.

${ }^{26}$ C. Gupta, Sexuality, Obscenity, Community: Women, Muslims, and the Hindu Public in Colonial India (New York, 2002), p.111.
} 
This is the accepted version of an article published in Journal of the Royal Asiatic Society Vol. 27 (4), 591-610 by Cambridge University Press. Available at: $\mathrm{https}: / /$ doi.org/10.1017/S1356186317000311 @ Richard David Williams

Accepted version downloaded from SOAS Research Online: $\underline{\text { http://eprints.soas.ac.uk/24618/ }}$

impractical. ${ }^{27}$ Confusion persisted over how to distinguish a dancing girl from a prostitute. ${ }^{28}$ A columnist in the Lucknow-based newspaper Karnama commented in 1871 that the Lock Hospital Act was inadequate since it was enforced inconsistently:

Now prostitutes and concubines, who have settled themselves with one lover, or whose profession is only to sing and dance, are exempted from the Act, and now they are again brought to trial. One officer takes one course, which is changed by his successor. ${ }^{29}$

Certain policies were unsuccessful precisely because it was known that 'prostitutes' were held in high esteem: 'the condition of the women is far less degraded, and their influence in the community often considerable, so that unwise interference would be frequently resented even by the influential classes of the people'. ${ }^{30}$ The uncertainty over how to distinguish between musical performance and sex work persisted, as men from elite or aspiring families continued to visit courtesans and pay for dancing girls. ${ }^{31}$

Vernacular urban newspapers indicate that at times dancing girl culture was on the rise, especially following the devastating famine of 1877-8: many famine victims turned to the dance and sex industries to obtain some livelihood. This is confirmed - and condemned - in a newspaper from Agra, which noted that dancing girls and prostitutes (reference was made to both) were convicted in the criminal courts for buying the daughters of famine-stricken families. ${ }^{32}$ A journalist from Lahore noted an 'immense increase' in dancing girls in almost every town, 'due to the encouragement which they receive at the hands of the public on festive occasions.' ${ }^{33}$ While we have to read these sources critically,

\footnotetext{
${ }^{27}$ Legg, pp. 1459-66.

${ }^{28}$ E.g. a debate in 1867 over whether 'naikeens' (singing women) were different from 'kusbeens' (public women who might also perform), in relation to which activities could be taxed. Finance Dept., Separate Revenue A, March 1868, 30-32 (National Archives of India); c.f. Central India Agency, Indore Letter Receipts, $1872,162$.

${ }^{29}$ Karnama, 28 August 1871, Selections from the Vernacular Newspapers Published in the Punjab, NorthWestern Provinces, Oudh and Central Provinces (Hereafter abbreviated Selections NWP) iv, p. 508.

${ }^{30}$ T. Farquhar in 1869, cited in Legg, p. 1464.

${ }^{31}$ Novels such as Premchand's Sevasadan (1918) reflect a mature stage of this cultural confusion, in which poor but pious women were compared to successful but 'immoral' singers. See V. Dalmia, 'Visions of a New Banaras and the New Novel in Hindi', in M. Gaenszle and J. Gengnagel, Visualizing Space in Banaras: Images, Maps, and the Practice of Representation (Wiesbaden, 2006), pp. 325-347.

${ }^{32}$ Nasim-i-Agra, 30 June 1878, Selections NWP, xi, p. 581. For a sense of the famine in the region adjacent to Agra, especially Mathura, see F.S. Growse, Mathurá: A District Memoir (Ahmedabad, 1978 [1883]), pp. 23-25. There were concurrent stories of purchasing girls in Lucknow, Oudh Punch, 9 July 1878, Selections NWP, xi, pp. 606-7. Besides the famine, Legg has shown that following revisions to the Cantonment Act in 1890, prostitutes were expelled from the regimental bazaars of military cantonments and settled in central urban areas: Legg, pp. 1465-1466.

${ }^{33}$ Selections NWP, xi, p. 497. C.f. Mashir-i-Qaisar, 26 March 1880, Selections NWP, xiii, p. 241; c.f. Rahbar-iHind, 20 April 1880, Selections NWP, xiii, p. 286.
} 
This is the accepted version of an article published in Journal of the Royal Asiatic Society Vol. 27 (4), 591-610 by Cambridge University Press. Available at: https://doi.org/10.1017/S1356186317000311 @ Richard David Williams

Accepted version downloaded from SOAS Research Online: http://eprints.soas.ac.uk/24618/

they gesture to the prevailing popularity and patronage of female artists, despite the polemic against them in the press. Indeed, the same complaints continued through to the end of the century, suggesting that the reformist agenda faced an uphill struggle.

\section{Sex and the city}

Urban society's fascination with women performers is well attested in literature and aesthetic theory. A long-established tradition of describing cities through its womenfolk continued into the colonial period, though often tempered by new moralising discourses. ${ }^{34}$ Many writers included extensive descriptions of the different female entertainers of Calcutta, from dancing prostitutes to celebrity bäìji singers, when they described the city. Kaliprasanna Sinha's Hutom Pyānicār Nakśā ('Sketches of the Brown Owl', 1862) mocked the playboy lifestyle of the urban babu elites, especially the attention they lavished upon (male and female) khemt $\bar{a}$ dancers and the singers of devotionals (kìrtan) and love songs (kheur and jhumur). ${ }^{35}$ In Debgaṇer Marttye Āgaman ('The Gods' Trip to Earth', 1880), Durgacaran Ray imagined a tour group of gods exploring famous cities and landmarks, in effect crafting a guide book to the subcontinent. Durgacaran characterised Calcutta through a series of brothels, dance recitals, and salons. The diversity of public women was almost an index of cosmopolitanism. Mortal tourists also described Calcutta in these terms, including one Malay visitor, Ahmad Rijaluddin in his Hikayat Perintah Negeri (c.1810), which gives an extensive account of the 'thousands of whores,' starting with the shipyards and proceeding into the depths of town. ${ }^{36}$ Rijaluddin noted how the women were from different regions, with identifiably distinctive features and clothes:

whores of different races such as Indians [i.e. Hindustanis], Pathans, Eurasians, and Hindu Bengalis, all of them young and fair... They sing one song after another accompanied by the sitar, fiddle and tambourine, the noise echoing down the lane.

\footnotetext{
${ }^{34}$ There are many examples of this in classical and vernacular literatures, including: in Brajbhasha, the Nagar Śobhā of Rahim, which gives sexualized accounts of women by profession; in Persian, the Muraqqa'-i Dehli of Dargah Quli Khan (c.1739), which catalogues courtesans and dancing boys along with musicians and marsiyakhwans; and Mina Bazār, attributed to Zuhuri and to Mirza Muhammad Iradat Khan Vazik (d.1716), which begins a description of a city with a description of a woman's bazaar (zananah bazār). See V. Miśra and G. Rajnīśa, Rahīm Granthāvalī (New Delhi, 1985), pp. 109-123; S. Sharma, 'The City of Beauties in Indo-Persian Poetic Landscape', Comparative Studies of South Asia, Africa and the Middle East 24:2 (2004), pp. 73-81, here 76.

${ }^{35}$ S. Roy, The Observant Owl: Hootum's vignettes of nineteenth-century Calcutta: Kaliprasanna Sinha's Hootum Pyanchar Naksha (Kolkata, 2008); D. Ray, Debganer Marttye Āgaman (Calcutta, 1880); H. Herder (2004). 'The Modern Babu and the Metropolis: Reassessing Early Bengali Narative Prose (1821-1862)', in S.H. Blackburn and V. Dalmia, India's Literary History: Essays on the Nineteenth Century (Delhi, 2004) pp. 358-401; S. Banerjee, Logic in a Popular Form: Essays on Popular Religion in Bengal (Kolkata, 2002).

${ }^{36}$ C. Skinner, Ahmad Rijaluddin's Hikayat Perintah Negeri Benggala (The Hague, 1982).
} 
The singing is quite delightful, and many of the passers-by are struck dumb with admiration for their beautiful voices, while the more susceptible go into the brothels to dance with the whores, this is what goes on here. ${ }^{37}$

This cataloguing of diverse genres and regional backgrounds was especially valued in Indian works on aesthetics. Classical poetics (kāvya) traditionally elaborated the different facets and connotations of women, distinguishing them by locale, marriage status, class, age, and emotion. ${ }^{38}$ Variety was the spice of life.

There were many ways to read a works on aesthetics, music, or other allied knowledge systems, but it should be recalled that these texts were intertwined with literature relating to connoisseurship, comportment, and ethics. The connoisseur guarded himself against emotional entanglement with unworthy objects, be they works of art or performing bodies.

In the nineteenth century, musicologists writing in Urdu wove together literary associations with racialized stereotypes and an appreciation of localised musical styles. This is especially apparent in the Ghunca-yi Rāg (1863) of Muhammad Mardan 'Ali Khan. Khan maintained that dance styles were conditioned by the region where they were developed, especially the climate and beauty of local women. Kashmiri dance was the most notorious and world-renowned, while God had bestowed beautiful women and dances upon Punjab, while in Hindustan music and dance were 'beguiling' (fireb). Khan also described the salacious dance of Bengal: 'the immodest (be-parda) dance is khemt $\bar{a}-$ the destroyer of piety and the breaker of repentance (ghärat-i imān wa tauba shikan).' ${ }^{39}$ Khan was especially effusive about dance in Lucknow, which had transformative properties when performed correctly:

The music, dance, and art of gesture ( $g \bar{a} \bar{n} \bar{a}, n \bar{a} c h, b a t a \bar{n} \bar{a})$ of Lucknow is extraordinary. Each expression (bhāv) is matchless. According to the Hindus, the creators of dance (raqs ) were undoubtedly Mahadev and Parvati, but for a long time in Hind the kathaks have been talented and skilled in it. In dance the gharānā of Miyan Abdullah and Pragās is the most celebrated of its time. Talk of them is in every city. By putting on airs an old man of some years becomes a glittering beauty, so that just looking at his postures $(t h \bar{a} t h)$ would make a man swoon... Those $\underline{t} a w \bar{a}^{\prime}$ if who have taken instruction from them, are also brilliant - they are described as beautiful and even as prodigies (le-bhāgu , i.e. they pick up ideas and run off without being taught). ${ }^{40}$

\footnotetext{
${ }^{37}$ Ibid., p. 95.

${ }^{38}$ E.g. the deśabheda (regional varities) of nāyika in Dev's (fl.1673-1743) Rasavilāsa 5.28-5.59. See L. Malviya, Dev Sampūrṇ Granthāvalī (Delhi, 2002), ii, pp. 193-199. On the fate of the nāyika in colonial painting, see R. Chattopadhyay and T.G. Thakurta, 'The Woman Perceived: the changing visual iconography of the colonial and nationalist period in Bengal', in Indian Women: Myth and Reality, ed. J. Bagchi (London, 1995), pp. 147-167. ${ }^{39}$ M.M.A. Khan, Ghunca yi Rāg (Lucknow, 1863), pp. 121-123.

${ }^{40}$ Khan, pp. $123-124$
} 
This is the accepted version of an article published in Journal of the Royal Asiatic Society Vol. 27 (4), 591-610 by Cambridge University Press. Available at: https://doi.org/10.1017/S1356186317000311 @ Richard David Williams

Accepted version downloaded from SOAS Research Online: $\underline{\text { http://eprints.soas.ac.uk/24618/ }}$

This treatise therefore gestures to how the reputations of individuals and entire cities circulated across the subcontinent. Combining poetic attitudes with travelling tales of expert dancers and $\underline{t} a w \bar{a}^{\prime} i f$ gave certain places distinct reputations in the world of performing arts.

On the one hand, this meant cities like Calcutta, which were home to women from many different regions, were seen as culturally rich and aesthetically diverse. On the other, it also put pressure on Bengali women in the city to align themselves with different regions and places, in order to appeal to cosmopolitan patrons with a taste for the expertise of Lucknow or the beauties of Punjab. Cultural connotations about urban femininity therefore determined how women marketed themselves, changing their reputations by training in music, dance and literature. Sumanta Banerjee noted how classically trained bāìjis in Calcutta pushed themselves apart from lower class khemt $\bar{a}-v \bar{a} l \bar{l}$ s by recasting themselves as Hindustani singers rather than Bengali dancers, learning Urdu and Persian, concealing their Bengali accents, and developing new repertoires. Although all these women lived in the same areas of the city and were largely from similarly poor, rural backgrounds, identification with the courtly culture of upper India was a means to attract a different kind of customer, and to achieve some form of social mobility. ${ }^{41}$

\section{Women's words}

When she spoke her melodious words, it was as though she were playing her inner flute.

People say the cuckoo's voice is beautiful, but listening to her it seems dull. The woman's words are matchless, they sustain life and remove worry, When he hears her speak, the sage's mind is disturbed. ${ }^{42}$

While the courtesan is usually thought of as a singer (gānevāili) and dancer (nācnevālì), many women were characterised by, and celebrated for, their eloquent speech. ${ }^{43}$ In Lucknow, polished language articulated the prized virtues of cultural refinement (tah $\underline{\imath} i b)$, propriety (shāyistagì), and a softly-spoken, reposed demeanour (șalāhinat). ${ }^{44}$ Courtesans deployed

\footnotetext{
${ }^{41}$ Banerjee, pp. 12-13, 114, 193-194. C.f. Gangamoni bāijī who taught the impoverished Binodini Dasi how to sing as a child, before she embarked on a successful career in theatre. See B. Dasi and R. Bhattacharya, My Story and My Life as an Actress (New Delhi, 1998), pp. 63-65.

42 Description of the courtesan Kamakandala in Mādhavānal (1582). Hindi text in R. Mishra (ed.), Mādhavānal Kāmakandhalā (Allahabad, 1982), p. 17.

${ }^{43}$ C.f. Horodwich on the courtesans of Venice: 'courtesans distinguished themselves primarily through their speech and language. They asserted their power and negotiated their status through the mastery of the spoken word.' E. Horodowich, Language and Statecraft in Early Modern Venice (New York, 2008), p. 166.

${ }^{44}$ Husain, p. 180.
} 
This is the accepted version of an article published in Journal of the Royal Asiatic Society Vol. 27 (4), 591-610 by Cambridge University Press. Available at: https://doi.org/10.1017/S1356186317000311 @ Richard David Williams

Accepted version downloaded from SOAS Research Online: $\underline{\text { http://eprints.soas.ac.uk/24618/ }}$

language in different modes: elegant conversation; composing poetry; reciting poetry; singing poetry; singing non-lexical lyrics; and casting spells. All these functions of the voice related to the possibility of enchantment, and male authors warned against the dangers of entrapment. An early nineteenth-century guide to Indian customs cautioned its readers against the magical tools at a courtesan's disposal. ${ }^{45}$ These practices - which ranged from strategic Qur'anic recitation to uttering supplications to trees, or making charms from donkey semen - were seen as different aspects of the courtesan's ability to manipulate men: her music recitals offered but a glimpse of her dangerously enchanting repertoire. ${ }^{46}$

Feminine forms of speech were both appreciated and condemned in Urdu poetry circles, especially when affected by men. Poets such as Sa' adat Yar Khan 'Rangīn' (17551835), Shaikh Qalandar Baksh 'Jur'at' (1748-1810), and Mir Yar Ali ‘Jān Ṣāḥ ib’ (1817-96) cultivated $r e \underline{k} \underline{h} t \bar{i}$, a gender-bending style of verse centred on the experience of domestic women, courtesans, and servants in a world ornamented by urban fashion and material glamour. ${ }^{47}$ Rekh tī relished the pleasures enjoyed by women, and was expressed in a highly colloquial language that was marked as a woman's style of speech (auratori ki zubān or begamati zubān). ${ }^{48}$ Critics of rekh tī characterised Ranginn's verse as the speech of whores

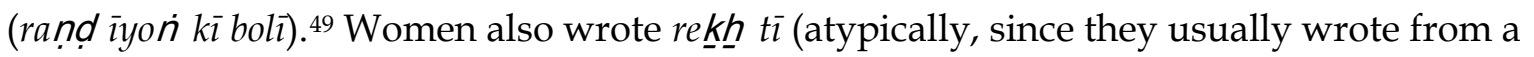
male vantage point (rek $\underline{h}$ ta) or, following Persian aesthetics, hid their gender with ambiguous grammar). At least two of Wajid 'Ali Shah's wives are known to have composed reḳh ti: his senior wife, Khas Mahal (c.1817-1894), who under the taḳh alluṣ 'Ālam was a more prolific lyricist than her celebrated husband; and Rashk Mahal ‘Begam', a Punjabi dancer and poet. 50

Besides stylized begamati zubān, women poets were also recognised for their eloquence, literary flair, and artistic articulations in performance. Although only a few voices have been traced in the archive thus far, it is apparent that early modern courtly

\footnotetext{
${ }^{45} \mathrm{~J}$. Shurreef, Qanoon-i-Islam or the Customs of the Mussalmans of India, Eng. tr. by G.A. Herklots (London, 1832), p. 342.

${ }^{46}$ Shurreef, pp. 343-344.

${ }^{47}$ R. Vanita, Gender, Sex, and the City: Urdu Rekhti Poetry in India, 1780-1870 (New York, 2012).

${ }^{48} \mathrm{G}$. Minault, Gender, Language, and Learning: Essays in Indo-Muslim Cultural History (Ranikhet, 2009) pp. 116-134.

${ }^{49}$ Vanita, p. 7.

${ }^{50}$ Vanita, p. 6. M.A. Bari, Tažkirat-ul Kֵ havātīn (Lucknow, 1900), p. 35. Petievich suggests that Rashk Mahal was confused with a male rekhhti poet who shared the takhalluṣ 'Begam': see C. Petievich, 'Feminine Authorship and Urdu Poetic Tradition: Bahāristān-i Nāz vs Tažkira-i Reknhtī , in K. Hansen and D. Lelyveld, A Wilderness of Possibilities: Urdu Studies in Transnational Perspective (New Delhi, 2005) pp. 223-250, here 237-8. On Khas Mahal see R.D. Williams, 'Hindustani music between Awadh and Bengal, c.1758-1905', unpublished doctoral thesis, King's College London (2015), pp. 176-206.
} 
This is the accepted version of an article published in Journal of the Royal Asiatic Society Vol. 27 (4), 591-610 by Cambridge University Press. Available at: https://doi.org/10.1017/S1356186317000311 @ Richard David Williams

Accepted version downloaded from SOAS Research Online: http://eprints.soas.ac.uk/24618/

culture facilitated the education of elite women - including members of the aristocracy and courtesans. ${ }^{51}$ Noted Urdu women poets from the eighteenth century included aristocrats (e.g. Begam Jan Bahu Begam 'Jani', wife of Nawab Asafuddaulah) and dancing girls (e.g. Muhammadi Begam of Faizabad, in Shujauddaulah's military camp). ${ }^{52}$ Scholars of the nineteenth century suggest that women's reading cultures changed dramatically under colonialism. After the 1830s elite women became less autonomous, as their financial influence was curtailed and domestic spaces were politically disenfranchised; from the midcentury onwards reformist literature re-fashioned the expectations and obligations of the modern woman, including how and what she should read. ${ }^{53}$ It was acceptable for upper class Muslim women to receive instruction in religious and advice literature, and perhaps Persian poetry, while marsiya recitation continued to be considered a respectable form of performance. ${ }^{54}$ Pernau notes that concomitant social changes hardened the 'boundaries between honourable women and their 'Other,' the courtesans and women from the lower classes, who could not afford to follow the rules of female segregation... as had the boundaries between the private and public spheres.' 55 Crucially, for women's literary practices, 'the world of the poets remained closed to respectable women - the recitation and singing of the ghazal was too closely associated with courtesans.' 56

Nonetheless, men and women who were deeply entrenched in the older, prereformist cultures resisted these boundaries. A particularly clear example is the aforementioned queen of Awadh, Khas Mahal, who published several of her own works, and composed a large collection of lyrics for her husband's song anthologies. ${ }^{57}$ Married to the man that embodied Nawabi decadence, it is tempting to dismiss her achievements as an aberration, permitted by her unusually high social status and her notoriously permissive husband. However, this would be a mistake. Khas Mahal took her position as a pardanishin

\footnotetext{
51 The Braj poet-theorist Keshavdas assumed his work would be available to literate women and describes the courtesans he instructed. See A. Busch, Poetry of Kings: The Classical Hindi Literature of Mughal India (Oxford, 2011), pp. 39-40. For women letter writers in pre-modern literature and painting, see $S$. Chakravarti, Patralekha: Romance of Letters in Indian Art and Literature (Naihati, 1996).

${ }^{52}$ M. Umar, Urban Culture in Northern India during the Eighteenth Century (New Delhi, 2001), p. 70. Persian women poets were featured in an eighteenth-century tazkira, the Riyāz al-Shu'arā (1749). See N.L.M. Tabor, 'A Market for Speech: Poetry Recitation in Late Mughal India', unpublished doctoral dissertation, The University of Texas at Austin (2014) pp. 79-87.

${ }^{53}$ Minault; B.D. Metcalf, Perfecting Women: Maulana Ashraf 'Ali Thanawi's Bihishti Zewar (Berkeley and Los Angeles, 1992); K. Sangari and S. Vaid, Recasting Women: Essays in Colonial History (New Delhi, 1989).

${ }^{54}$ C.M. Naim, 'How Bibi Ashraf learned to read and write', Annual of Urdu Studies 6, pp. 99-115; Petievich, p. 243.

${ }^{55}$ M. Pernau, Ashraf into middle classes: Muslims in nineteenth-century Delhi (New Delhi, 2013), p. 136.

${ }^{56}$ Pernau, p. 142.

${ }^{57}$ E.g. K. Mahal, Masnavī-i-'Ālam (Calcutta, 1866).
} 
This is the accepted version of an article published in Journal of the Royal Asiatic Society Vol. 27 (4), 591-610 by Cambridge University Press. Available at: https://doi.org/10.1017/S1356186317000311 @ Richard David Williams

Accepted version downloaded from SOAS Research Online: $\underline{\text { http://eprints.soas.ac.uk/24618/ }}$

queen extremely seriously, and preserved her respectability in tact: printing collections of ghazal and $t$ humrī did not impinge on her propriety.

More significantly, late nineteenth-century poetic tazkiras of women poets indicate that a larger sample of courtesans and respectable women were recognized as skilled poets over the course and in the wake of these transitions in colonial society. The tazkira was a popular genre in Urdu literature: anthologisers would compile directories of poets they knew personally or had heard of, providing biographical details and sample verses. Tazkiras dedicated exclusively to women was a novelty, and the juxtaposition of 'prostitutes' with pardanishin poets in these anthologies not only challenges the boundary between their social worlds, but also indicates a society of male readers and connoisseurs that was appreciative of their artistic labour. As will be shown, some of the men connected to these women were not castaways from a moribund Mughal culture, but very much involved in the colonial regime: these texts suggest the arena of journal polemic, ethical reform, and middle-class denunciation of dancing girls was not entirely normative in this period, and that societies of appreciative men continued to value - perhaps even fetishizewomen's speech.

\section{Collecting and recollecting women}

At least three men are known to have compiled anthologies of women poets over the late nineteenth and early twentieth centuries. ${ }^{58}$ Muhammad Fasihuddin 'Ranj' of Meerut (183685) first assembled the Bahāristān-i-Nāz ('Springtime Garden of Coquetry') in 1864, which grew substantially over two further editions in 1869 and 1882, culminating in a selection of 174 Urdu and Persian poets. ${ }^{59}$ In the intervening years, Durgaprasad 'Nādir' of Delhi compiled the Gulshan-i Nāz ('Rose Garden of Coquetry', 1876), a short tazkira prefaced by an essay on Islamic perspectives on women's writing. Encouraged by its positive reception, Nādir quickly compiled the more substantial Tazkirat al-Nisā Nādirī ('Nādir's Anthology of Women'), 1878, also called Chaman-i Andāz or Mirat-i-Kh ayāì). Some fifty years later Maulvi Abdul Bari drew on both Ranj and Nadir for his own anthology, Tazkirat-ul-ḳh awātīn ('Anthology of Ladies', c.1930).

\footnotetext{
58 Petievich suggests that Urdu women poets were first included in tazkiras from the early 1800s, as in the Iabqa'āt-us-Sho'arā of Qudratullā Shauq (d.1809). See C. Petievich, 'Feminine Authorship and Urdu Poetic Tradition: Bahāristān-i Nāz vs Tažkira-i Rek khtî', in Hansen and Lelyveld, pp. 223-250, here p. 223. Selections from these works have recently been re-published: F. Najaf, Bāzār-i Husn kī shā'irāt (Lahore 2012).

59 Petievich, pp. 227ff; Sachdeva, pp. $200 \mathrm{ff}$.
} 
This is the accepted version of an article published in Journal of the Royal Asiatic Society Vol. 27 (4), 591-610 by Cambridge University Press. Available at: https://doi.org/10.1017/S1356186317000311 @ Richard David Williams

Accepted version downloaded from SOAS Research Online: http://eprints.soas.ac.uk/24618/

The compilers (tazkira-nigār) organized the women alphabetically by their pen name (takn alluṣ), and provided each one with a brief biography, beginning with where she lived or performed, recording anecdotes and male poets associated with her, and finishing with sample verses. This format was identical to compilations of male poets - indeed, many of the biographical entries were longer than those in some male-dominated anthologies, such as Tazkirah-i Shamim-i Suknh an (1891). ${ }^{60}$ In her study of Ranj, Carla Petievich suggests an ambivalence in his appraisals: going to the effort of compiling and installing these different authors into the established tazkira genre suggests that Ranj recognised their literary merit and cultural value to some degree; then again, his annotations are often salacious and irreverent. Belittling the merit of even well known poets, such as Mah Laqa Bai 'Chandā', Ranj appears to suggest that as 'quasi-public women,' "“poetesses" should enter the historical register, but perhaps not on the same line as male poets.' ${ }^{61}$ However, there are difficulties with Chandā's entry: she was not featured in early editions of Bahāristān-i Nāz, and was later illustrated by only one verse, which makes it is quite possible that Ranj had not actually seen her diwān or heard any examples of her poetry. As such he could comment on her reputation but not her literary merits. While the tazkira-nigārs are sensationalist in certain cases, that these anthologies were produced at all, in a time of increasing sensitivity or outright hostility towards courtesan culture, is significant.

Sachdeva notes that publishing poetry provided a new public platform for $\underline{t} a w \bar{a}^{\prime} i f$, who 'used specific techniques of self-hood or subjectivity in conjunction with technologies of leisure such as commercial printing to become celebrity entertainers in cities.' 62 However, this self-fashioning was mediated: by the Urdu poetry itself - which articulates emotions through pre-determined tropes - and by the men who anthologised and disseminated the poets' compositions. Terry Kawashima has argued that the marginalisation of women in literature is not a clear-cut condition but a haphazard process: the same can be said of the courtesan poets and their male associates, who did not marginalise the women per se, but created a separate quasi-canon for them on the basis of gender. ${ }^{63}$ Many of these women were publishing their own diwāns, which provided the anthologisers with some of their example

\footnotetext{
${ }^{60}$ A.H. Safa, Tazkirah-i Shamim-i Sukhan (Lucknow, 1891)

${ }^{61}$ Petievich, pp. 230-42. C.f. S. Kugle, 'Mah Laqa Bai and Gender: The Language, Poetry, and Performance of a Courtesan in Hyderabad', Comparative Studies of South Asia, Africa and the Middle East 30:2 (2010), pp. 365385.

62 Sachdeva, p. 195.

${ }^{63}$ T. Kawashima, Writing Margins: The Textual Construction of Gender in Heian and Kamakura Japan (London, 2001).
} 
This is the accepted version of an article published in Journal of the Royal Asiatic Society Vol. 27 (4), 591-610 by Cambridge University Press. Available at: https://doi.org/10.1017/S1356186317000311 @ Richard David Williams

Accepted version downloaded from SOAS Research Online: $\underline{\text { http://eprints.soas.ac.uk/24618/ }}$

verses. A feminine taz kira was an appealing novelty in the market - granting insights into networks of esteemed male poets, the salons of celebrated courtesans, and even into the homes of secluded, aristocratic women. ${ }^{64}$ It is tempting then to consider these anthologisers as book entrepreneurs, expanding their tazkiras with each edition to meet the demand of their reader-consumers. At the same time, the anthologisers deployed the framework of the tazkira to create a respected space for women poets and, by extension, the literary-cumperformance culture these men valued. 65

The entries for contemporary women poets reflect a sense of increased movement in the wake of 1857, since many women are said to have migrated between two or more cities. Successful dancing girls had always been mobile, as with women like Jivani (d.1804), who wrote as Șanaubar ('Pine tree'): she was from Jalandhar, but belonged to a troop (zumra) of $\underline{t} a w \bar{a}^{\prime} i f$ based in Delhi. ${ }^{66}$ Many of the poets contemporary to Ranj were on the move, especially from Lucknow to Calcutta: after Wajid 'Ali Shah relocated there in 1856, following the Annexation of Awadh, he built a substantial musical community in the southern suburb of Matiyaburj, so it makes some sense that Lakhnavi courtesans followed the patrons who gathered around him.

Jafri, a $\underline{t} a w \bar{a}$ 'if and long-time resident of Lucknow, 'took correction' from Munshi Fadā Hussain 'Faẓ ā', but then later moved to Calcutta (and was still alive in 1872). ${ }^{67}$ Migrations were often the only biographical details available to Ranj, as with a woman known to poets as 'Sharm':

Sharm ['Modesty' /'Shame'] - Choti Sahab, she was a $\underline{t} a w \bar{a}$ 'if and resident of Lucknow, and then she also went to Calcutta. [The poet] Maulavi 'Abdul Ghafur Khan Sahab 'Nassākn ' ' wrote that he had seen her. This is one [of her] verse[s]:

Mourdah zindah ho gaye pa-zeb ki jhankar se Har qadam par hasher bar pā hai teri raftar se

The dead have come alive from the tinkling of anklets:

On every step a commotion is stirred up [or, the dead are raised up] by your gait.

Yeh kis rashk mah ka nazz āra ā hua hai

\footnotetext{
${ }^{64}$ Sachdeva, pp. 209-210. This situation resonates with the role of the poligrafi in sixteenth-century Italyeditors, agents, and translators-who were heavily involved in compiling and editing women writers in a 'new, market-led literary culture enabled by print technology.' V. Cox, Women's Writing in Italy 1400-1650 (Baltimore, 2008), p. 82.

65 On contemporary anthologies of women poets in Iran, see D. Brookshaw, 'Qajar Confection: The Production and Dissemination of Women's Poetry in Early Nineteenth-century Iran', Middle Eastern Literatures 17:2, pp. 113-46.

${ }^{66}$ M. Ranj, Bahāristān-i-Nāz (Merut, 1869), pp. 42-3.

${ }^{67}$ M.A. Bari, Tazkkirat-ul-khawātīn (Lucknow, 1930?), p. 36.
} 


\section{Ki kh w urshed ankhon ka tārā hua hai}

What envy of the moon has come into sight, such

that the sun has become a star 68 in her eyes?

Mile ghir se yār ankhon ke āge

Mere jān yeh kisko gwārā hua hai ${ }^{69}$

Before my eyes, my beloved meets with another.

My love! Who can tolerate this?

These couplets (sher) would serve as a link in a longer ghazal chain. Ghazals were commonly recited by men and women alike at poetic gatherings, the mushairas, but it some were evidently intended for singing, since we have ghazals in song anthologies as well as poetic compendia. ${ }^{70}$ The excitement aroused by the anklet could be amplified in a physical performance, exploring the words through dance while Sharm sang, tingling her anklets. In the moment of performance Sharm effectively sang in dialogue with herself: her words are directed to a dancer in the second person, 'your (teri) gait', yet she embodied that dancer herself. The option of the split persona is a familiar device in Indian dance, allowing the performer to slide between the roles of narrator and the characters implied in the lyrics. Since the lyric is her own, Sharm is singing playfully about herself, using her own words. ${ }^{71}$ The reaction she excites is earth-shattering and raises the dead - hashar ('tumult') is a pun here, referring to the 'commotion' of the jingling, but is also synonymous for the day of resurrection. This imagery had been used elsewhere in relation to a beautiful gait, and in Tilism-e-Hoshruba ('The Sense-Stealing Charm') the trope was applied to a handsome warrior rather than a nimble dancing girl: 'Even the dead in their graves opened their eyes to admire his bursting youth and winsome gait.'72 Sharm's lyrics were textured with allusions and different possibilities for discursive and embodied interpretations, glossing the danced performance with a sense of cosmology and theology, magnifying the moment through enacted poetry.

In this entry, we are told that Maulavi 'Abdul Ghafur Khan Sahab 'Nassāknh ' (183489) had seen Sharm. The tazkiras are peppered with references to well-known male poets: some had merely noted seeing the women, while others taught or had intimate affairs with

\footnotetext{
${ }^{68} \operatorname{Ta} r a \overline{-}-$ light or pupils.

${ }^{69}$ Bari, pp. 90-1.

70 e.g. W.A. Shah, Nāju (Calcutta, 1869) and Dulhan (Calcutta, 1873).

${ }^{71}$ Mah Laqa Bai used a similar technique in her own verses, see Kugle, pp. 371-2.

${ }^{72}$ M.H. Jah and M.A. Farooqi (trans.), Hoshruba: The Land and the Tilism, Tilism-e Hoshruba: Book 1 (Noida, 2009), p. 77.
} 
This is the accepted version of an article published in Journal of the Royal Asiatic Society Vol. 27 (4), 591-610 by Cambridge University Press. Available at: https://doi.org/10.1017/S1356186317000311 @ Richard David Williams

Accepted version downloaded from SOAS Research Online: http://eprints.soas.ac.uk/24618/

them. Although it is tempting to think of courtesans as building a world for themselves outside mainstream patriarchal society, ${ }^{73}$ these women evidently operated through networks of cultured men to acquire education and patronage. When Malka Jan (the mother of Gauhar Jan) settled in Banaras in 1879, she undertook training from local specialists: Persian composition with Hussain Ahmed Asghar and Qadar Hussain; Urdu with Hakim Banno Sahib 'Hilal'; musical training with Zeenat Bibi of Banaras and later Kalloo Ustad, and dance with 'Ali Baksh of Lucknow. ${ }^{74}$ When she published an anthology of some 600 ghazals, the Makn zan-e-Ulfat-e-Mallika ('Mallika's Store of Affections', Calcutta 1886), the work was printed with verses celebrating her achievement by Maluvi Muhammad 'Shams' of Calcutta, Shireen Jan of Lucknow, Hafiz Ali 'Najaf' (disciple of Dagh Dehlvi), Hazrat Shams Lakhnawi, Munshi Yaqub Sahab 'Asar' of Awadh, Raghunath Sahai 'Ibrat' of Azimabad, and Ghulam Haidar Khan 'Muztar'. ${ }^{75}$ Male and female poets were entangled in the same society: while the mushaira was not an egalitarian space, the combination of men and women celebrating a courtesan poet's publication contrasts with the more familiar history of men writing to denounce or reform the 'fallen woman'.

Reflecting on the male poets who associated with courtesans suggests that there was a porous boundary between older cultures of literary and musical appreciation and new forms of society yoked to the colonial administration. Nassākn $\underline{h}$ was the younger brother of Nawab 'Abdul Latif (1828-1893) - founder of the Muhammadan Literary Society at Calcutta (1863) - and son of Qazi Faqir Muhammad, a Persian scholar employed at the Calcutta civil courts (Sadr Diwani Adalat). ${ }^{76}$ Nassāknh was trained by his father to be competent in Arabic, Persian, Urdu, Bengali and English, and also studied at the Calcutta and Hughly Madrasas. He was employed as a linguist in the Sadr Diwani Adalat, and then served as a Deputy Magistrate (Barisal) from $1860 .{ }^{77}$ His poetic works, including a tazkira called the Shukan-iShu'ara, were extremely well-regarded, and he is remembered by some as the 'father of Urdu poetry' in Bengal. ${ }^{78}$ Christopher Shackle characterised him as 'a lively provincial intellectual, ambitious for preferment under the nineteenth-century Raj at the same time as being more than amply anchored to the élite values of the Mughal past.' 79 His being a

\footnotetext{
73 Oldenburg.

${ }^{74}$ V. Sampath, 'My Name is Gauhar Jaan!': The Life and Times of a Musician (New Delhi, 2010), p. 17.

${ }^{75}$ Sampath, pp. 284-301; Sachdeva, pp. 219-26.

${ }^{76}$ S.M. Ikram, Indian Muslims and the Partition of India (New Delhi, 1992), pp. 93-5

77 M.M. Khan, The Muslim Heritage of Bengal (Markfield, 2013), pp. 126-31.

${ }^{78}$ A.G. Khan 'Nassāknh', Shukan-i-Shu'ara (Lucknow, 1874).

${ }^{79}$ C. Shackle, Bulletin of the School of Oriental and African Studies 50 (1988), pp. 584-5.
} 
This is the accepted version of an article published in Journal of the Royal Asiatic Society Vol. 27 (4), 591-610 by Cambridge University Press. Available at: https://doi.org/10.1017/S1356186317000311 @ Richard David Williams

Accepted version downloaded from SOAS Research Online: http://eprints.soas.ac.uk/24618/

magistrate was no obstacle to his deep involvement in courtesan culture, and Nassāknh appears regularly in the women's tazkiras. Along with his colleague Maulavi Ismatullah Saheb 'Mazbur' (later 'Azan'), he corrected several women's verses from his base in Pandua, Hooghly District: besides Sharam, his courtesan students included Hijāb (below), and one Zahra:

Zahra ('Shining') her pen name, Munni her name. Her ordinary business came from selling her beauty. Her original country was Kashmir, but then her livelihood drew her to Calcutta's bazaar. She was extremely beautiful and had a happy disposition. Sometimes, because of her balanced qualities, her lyrics too were balanced in metre. Maulavi Abdul Ghafur 'Nassākn ' - editor of the tazkira Shukan-i-Shu'ara-corrected her verses. She was alive until $1291 \mathrm{H}$ [1874]. This is her composition:

Dekhkar caurang dil hai aishq dilgīr kā

Sabzah-i rukhsar sabzah hai magr shamshir kā

Beholding this dismemberment, the heart fell in love with the morose.

The verdant fuzz of the cheek is but the bloom of the sword

Dil hamārā dard kā putlā banā āye brahman

He tașawwur dambadam jo us bat be-pīr kā

Oh Brahman! My heart has become the image of pain, Endlessly picturing that unfeeling idol. 80

Urban elite culture was not confined to the city proper, but emanated through networks of connoisseurs and patrons in satellite towns and countryside residences. British records (focusing on archaeology) suggested Pandua was a ruined or deserted city, but it was in fact a thriving cultural forum focused around two important dargāhs, ${ }^{81}$ and annually hosted two major fairs that attracted thousands of visitors. Nassākn and Mazbur were not the only Urdu and Persian litterateurs in residence: Muhammad 'Abid 'Ali Khan (b.1872) wrote primers in Urdu and Bengali, a local history, and a lyric anthology (Gulshān-i Hind). Khan did not see himself as a backwater intellectual: he was from a Pathan lineage and boasted that in his family Urdu 'conversation [was] very similar to that current in Delhi. Certain rites in our marriage ceremonies are the same as those that used to be observed in the Royal family at Delhi.' ${ }^{22}$ A community from Zaidpur in Awadh were also based locally, and Ghulām Husain Salīm Zaidpūrī (d.1818), author of the Persian history Riyāzu-s-Salàtīn

\footnotetext{
80 Bari, p. 68.

${ }^{81}$ The shrines of Makhdum Shah Jalal (d.1337) and Hazrat Nur Qutbul 'Alam (d.1415). See M.S.H. al-Masumi, 'Bengal's Contribution to Islamic Learning - I', Islamic Studies 6:2 (1967), pp. 155-170, here p. 167.

82 M.A.A. Khan and H.E. Stapleton (ed.), Memoirs of Gaur and Pandua (Calcutta, 1931), based on a text originally drafted in 1902.
} 
This is the accepted version of an article published in Journal of the Royal Asiatic Society Vol. 27 (4), 591-610 by Cambridge University Press. Available at: https://doi.org/10.1017/S1356186317000311 @ Richard David Williams

Accepted version downloaded from SOAS Research Online: http://eprints.soas.ac.uk/24618/

(1787-8), was buried in nearby Angrezabad. ${ }^{83}$ For the courtesans, Pandua was a significant centre of Indo-Persian literary culture only $55 \mathrm{~km}$ north of Calcutta. The traffic of poets and their pupils indicates an Urdu literary network, not only between larger cities, but coursing through networked households in smaller satellite towns. This corresponds to Mushirul Hasan's notion of qasbahs as 'the involuntary heirs of the once-powerful Indo-Persian culture, whose gifts they were to pass on in one direction or another.' 84 The references to geography in the tazkiras both authenticate women's positions in a moving network of male artists, but also demonstrate their local engagement with elite circles of cultural refinement and literary expertise.

One of the most notorious tales of mobile courtesans and poets was that of Hijāb and Dāgh. Outside of the mushaira, Hijāb was called Munni Bai; she was a $\underline{t} a w \bar{a}$ 'if from Colotulla Bazaar in Calcutta, and developed her poetry with Mazbur and Nassākn in Pandua, but she was also especially celebrated for her skills in music. ${ }^{85}$ She made a trip to Rampur, where she began a love affair with the poet Mirza Dāgh Dehlvi (1831-1905), which became part of her biography in the tazkiras. Dāgh had been educated in the Red Fort after his mother married Mirza Muhammad Sultan, son of Bahadur Shah Zafar. Contributing to the royal mushairas, Dāgh had been at the centre of the Mughal literary scene, and had studied with Muhammad Ibrahim Żauq (1789-1854). Following the destruction of Delhi, Dāgh moved with his family to Rampur, where he became a companion of the heir-apparent, Nawab Kalb 'Ali Khan (1832-1887) for some thirty years. In that time he toured through Delhi, Lucknow, Patna, and Calcutta, hosting and appearing at poetry assemblies, and finally moved to Hyderabad in 1888. ${ }^{86}$ He composed a masnavī called Faryād-i Dāgh (Dāgh's Lament), which chronicled his love for Hijāb, their encounter in Rampur, and their time together when he followed her back to Calcutta.

In his masnavi, Dāgh 'hints more than plainly that Hijab made it clear to him that it was not his dark complexion or his ordinary features that she admired, but she admired him

\footnotetext{
${ }^{83}$ Khan, pp. 12, 97, 160-1.

${ }^{84}$ M. Hasan, From Pluralism to Separatism: Qasbas in Colonial Awadh (New Delhi, 2004) p. 17. See also V. Oldenburg, The Making of Colonial Lucknow, 1856-1877 (Princeton, 1984), pp. 181-260; M. Robb, 'Interpreting the Qasbah Conversation: Muslims and Madīnah Newspaper, 1912-1924', unpublished doctoral dissertation, University of Oxford (2013); M.R. Rahman, 'Beyond centre-periphery: qasbahs and Muslim life in South Asia', South Asian History and Culture 5:2 (2014), pp. 163-178; Idem. 'Qașbas as Place: A Sense of Belonging and Nostalgia in Colonial India', Journal of the Economic and Social History of the Orient 58 (2015), pp. 668-692. ${ }^{85}$ Bari, pp. 52-53. Bari notes that she was young in 1881.

${ }^{86}$ R.B. Saksena, A History of Urdu Literature (Allahabad, 1927), pp. 186-187.
} 
This is the accepted version of an article published in Journal of the Royal Asiatic Society Vol. 27 (4), 591-610 by Cambridge University Press. Available at: https://doi.org/10.1017/S1356186317000311 @ Richard David Williams

Accepted version downloaded from SOAS Research Online: $\underline{\text { http://eprints.soas.ac.uk/24618/ }}$

as an artist in words.' 87 A poem commemorating the Benazir Fair of Rampur (where perhaps Dāgh and Ḥijāb first met ${ }^{88}$ ) describes Dāgh in literally glowing terms:

Among the poets of Delhi the Nawab Mirza is

The radiance [or touchstone, roshan] of the intellect, an ornament of light,

When he writes ghazals his takn alluṣ is Dāgh

In the company of poets he is a brilliant lamp. ${ }^{89}$

In later times, he was read less sympathetically: R.B. Saksena (1927) thought Faryād-i Dāgh was 'marred by pictures of sensuality and coarse passion and is occasionally revolting to fine taste.' 90 Saksena acknowledged that in Dāgh's own time his 'reputation as a facile writer of easy, smooth and eloquent erotic verses spread like wild fire', but with hindsight it could be said that Dāgh lacked 'the real pathos or pain of Mir, or the sublimity of thought of Ghalib.' ${ }^{11}$ Saksena presented a moderate assessment of Dāgh: harsher critics had apparently called him 'a poet laureate of dancing girls and his poetry has been dubbed the poetry of licentiousness and sensuality. These are extreme views which need considerable modification.' Saksena evidently admired the forms and techniques of Dāgh's poetry, but not the social implications of his affections:

His love has seldom any beauty, truth, sublimity, or refinement... The kisses and embraces of which he writes are the kisses and embraces which could be purchased and paid for. Many of his verses are not fit for decorous ears. They are fit to be sung, as they are sung in the banquets of pleasure in the company of riotous boon companions, lit with wine and laughter of dancing girls. They depict surface emotions and rarely strike a higher note. ${ }^{92}$

Downgrading Dāgh's feelings to 'surface emotions' indicates the boundaries between emotional communities. Saksena's critique was coloured by his disapproval of Nawabi culture: expressions of love were automatically tarnished by the taint of prostitution, and Dāgh's emotions could not be taken as sincere or meaningful. ${ }^{93}$

However, this condemnation was not universal. Dāgh was made notorious for his relationship with Hijāāb, but her teacher, Nassāknh was not. Dāgh may have immortalised his love in Faryād, but Nassākn published a work dedicated to the piecemeal description of a

\footnotetext{
${ }^{87}$ A. Qadir, Famous Urdu Poets and Writers (New Delhi, 1977), p. 101.

${ }^{88}$ This is alleged by Saksena, but Hijāb is not featured by name in the Musaddas.

${ }^{89}$ M.Y.A. Jan Sahib, Musaddas tahnīyat-i jashn-I benaẓir (Rampur, 1999), p. 142.

90 Saksena, p. 188.

${ }^{91}$ Saksena, pp. 188-190.

92 Saksena, p. 189.

93 On decadence in literature see C. Petievich, Assembly of Rivals: Delhi, Lucknow, and the Urdu Ghazal (New Delhi, 1992).
} 
This is the accepted version of an article published in Journal of the Royal Asiatic Society Vol. 27 (4), 591-610 by Cambridge University Press. Available at: https://doi.org/10.1017/S1356186317000311 @ Richard David Williams

Accepted version downloaded from SOAS Research Online: http://eprints.soas.ac.uk/24618/

beautiful woman's body (sarāpā), including her bodice and lap, in Shähid-i 'Ishrat ('Witness of Enjoyment', 1874): although this was an established genre, had critics wanted to condemn his taking on courtesan pupils, this sensual text would have been an easy target. Crucially, however, while Dāgh was a remnant of the Mughal court and a retainer of the controversial Rampur Nawabs, Nassākn w was a magistrate: the different social standing of the poets was critical to their different reception histories, and the perceived respectability of their emotions.

The tazkiras problematize assumptions about derogatory language. The compilers used a variety of terms to define the poets: $\underline{t} a w \bar{a}$ 'if appears regularly, but also bazāri (bazaargirl), maqbul-i bazār (mistress of the bazaar), and common words for prostitute or harlot, rand $\bar{i}$ and $k \underline{h} \bar{a} n g \bar{i} .94$ At first glance, it appears the compilers were belittling the poets as 'fallen women' in the style of the reformists. But two factors suggest otherwise. Firstly, these terms were consistently used with reference to bazaars and livelihoods (pesh, ma'āsh, äbo dāna), which appear almost as a separate consideration from the women as dancers (raqqāșa) or their skills in music, recitation, and writing. Although these terms are not sympathetic in themselves, in context these writers were not passing moral judgements when they used them to situate women they evidently admired. Secondly, these women were compiled alongside queens, aristocratic women, and other pardanishins. This suggests the persistence of a culture that valued poetic production over other social considerations: literary talent afforded all types of women access to a shared cultural arena, in spite of the opposition from other sections of the middle classes.

How the tazkiras commemorated the literary talent of women raises questions relating to the influence of gender in Urdu performance culture. On the whole, Ranj and the compilers who followed him were very effusive. Women were described as possessing the same abilities as men. This was explained, almost apologetically, in terms of talim. Bega 'Shirīn', a $\underline{t}$ awāi'f from Lucknow, studied with Muhammadi Sahib 'Sipahr', disciple of Khwaja Wazir Sahib, 95 and then with Shaikh Amdad 'Ali Sahib 'Baḥ r'. Ranj notes she flourished under their tuition, and 'although I have not seen the diwān, I have heard that her own diwān is delightful, considered, and subtly discerning (nukta-dān). ${ }^{96}$ The sister poets of Lucknow, Qamran Jan 'Mushtarī' ('Jupiter') and Umrao Jan 'Z oof('łkenus'), were

\footnotetext{
${ }^{94}$ khāngi usually refers specifically to a married woman who secretly was also a prostitute or had affairs.

95 See Khan Nassāknh, p. 208.

${ }^{96}$ Ranj, p. 41.
} 
This is the accepted version of an article published in Journal of the Royal Asiatic Society Vol. 27 (4), 591-610 by Cambridge University Press. Available at: https://doi.org/10.1017/S1356186317000311 @ Richard David Williams

Accepted version downloaded from SOAS Research Online: http://eprints.soas.ac.uk/24618/

especially well-regarded:97 Ranj tells us that Mushtarī had 'an incomporable claim in poetry, her temperament oozed with an extremely sharp discernment' ${ }^{98}$ The sisters were trained in poetry by a Lakhnavi ustād who had moved to Calcutta, Mirza Agha 'Ali 'Shams'. ${ }^{99}$ Ranj reasoned that the sisters shared their famous teacher's reputation for genius, 'and why should it not be so? For since the Ustād Jī would have spoken from his magnificent imagination when instructing them, so the student too consequently becomes a household name.' 100

Other women were judged to be considerably better than male poets, including Bannu of Delhi. Ranj introduced her to his readers as a $\underline{k} \underline{h} \bar{a} n g \bar{\imath}$, 'good in appearance and good-natured too... her style was delicate and visionary (nāzuk khh ayāli - with a moment's thought her words were superior to thousands of men: every moment of her letters, and every hour of her recitals (shěr $r-g o^{\prime} \imath$ ) was a delight.' ${ }^{101}$ Before presenting her verses, Ranj described the secret love between Bannu and Gulab Singh 'Āshufta', especially how Gulab Singh became inconsolable during a period of separation and slit his own throat. This episode was illustrated by Bannu's own grief-wracked verses, Ghalib's reflections on the incident, and the sad postscript that she died of tuberculosis. ${ }^{102}$ As Pernau notes, Āshufta's 'biography reads like a living ghazal', 103 as the male poet is literally slain, overwhelmed by the pain of 'separation in the real world' ('âlam zist men firāq). Gulab Singh becomes the 'disturbed' one - the literal meaning of Âshufta - while Bannu the wordsmith understands the devastating potency of her craft: Ranj described how when she heard about the suicide she was overcome with weeping, yet still spontaneously conjured a couplet, which 'she brought up to her tongue' (zabān par layi). This phrasing was idiomatic but pointed. The word 'tongue' (zabān), which also means speech, teases out the sensuality of the seductive poetess, tracing her enchanting compositions back to the organ of speech and her physicality. ${ }^{104}$ The episode is almost cautionary, illuminating the power of an articulate woman.

Ranj distinguished between Bannu's writing and her skills in recitation, and other entries in the tazkira also separate the different art forms in which the women specialised.

\footnotetext{
${ }^{97}$ Sachdeva, pp. 215-8.

${ }^{98}$ Ranj, p. 54.

${ }^{99}$ A.G. Khan Nassāḳh, Saḳhan-i Shu'arā (Lucknow 1874), p. 252.

100 Ranj, p. 54.

101 Ranj, pp. 24-5.

102 Ibid.

103 Pernau, p. 140.

${ }^{104}$ On the erotica of the mouth and the sexual dimension of literature, see Horodowich, pp. 169-72.
} 
This is the accepted version of an article published in Journal of the Royal Asiatic Society Vol. 27 (4), 591-610 by Cambridge University Press. Available at: https://doi.org/10.1017/S1356186317000311 @ Richard David Williams

Accepted version downloaded from SOAS Research Online: http://eprints.soas.ac.uk/24618/

Badshah Begam 'Kֵh afī', a $\underline{k} \underline{h}$ āngī who was intriguingly known in Anglophone circles as Missy Laqab, was praised as a poet (shä'ira) 'inclined towards reḳh ta-go'ì, and her shä'ir-go'i is an utterly perfect accomplishment.' These skills in recited composition (go'î) were

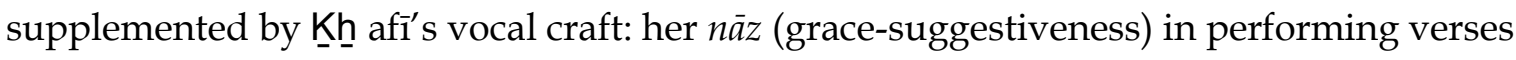

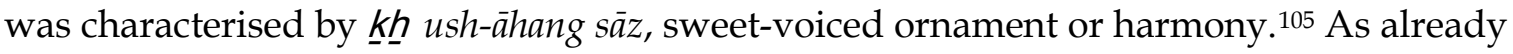
noted, Z ălơf Lucknow was celebrated as a both an Urdu and Poet poet, 'erudite in

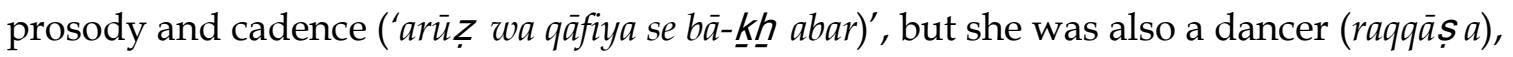
and her performed recitation of ghazal (ghazal-knh wān $\bar{\imath}$ ) was held in higher esteem than her composition $\left(g g^{\prime} \hat{\imath}\right) .{ }^{106}$ Although it is difficult to reconstruct how these women performed their verses, the the tazkiras take for granted nuanced differences between compositional $g^{\prime}{ }^{\prime} \bar{l}$, recitational $\underline{k} \underline{h} w \bar{a} n \bar{\imath}$, the danced müjra, and expertise in performance.

Celebrating women writers through the tazkira genre was particularly meaningful. By working with poetry, these women transcended their local affiliations to bazaars and troops, and had authentic access to a pan-regional, mobile network of literary performers, working alongside and sometimes competing against men. The biographical sketches confirm that following 1857 familiar patronage systems were unsettled, and female performers and writers moved between cities, especially from Lucknow and Delhi to Calcutta, Rampur, and other secure urban centres. At the same time, there is little sense of total disruption: women continued writing, forging connections with connoisseur networks, and performing. Their recurrent appearances in print underline that the most educated courtesans survived the upheaval of the Uprising and legislation of the 1860s and did not disappear. The record of male poets who taught these women suggests the cultural significance of smaller places, especially satellite towns around metropolitan centres. The variety of women listed (from pardanishin to rand $\bar{\imath}$ ) suggests that in poetry circles there was not as rigid a boundary between courtesans and married women in the nineteenth century as is often supposed: to these men, a woman might be considered a whore and a fine poet at the same time. Finally, the tazkiras bear testimony to the power of these women's language, which continued to be held in high esteem by the men who valued the Mughal society that these women's verses evoked.

\section{Conclusion}

\footnotetext{
105 Ranj, p. 32.

106 Bari, p. 217.
} 
This is the accepted version of an article published in Journal of the Royal Asiatic Society Vol. 27 (4), 591-610 by Cambridge University Press. Available at: https://doi.org/10.1017/S1356186317000311 @ Richard David Williams

Accepted version downloaded from SOAS Research Online: http://eprints.soas.ac.uk/24618/

The colonial city is usually thought of in terms of new technologies, ascendant middle class societies, and reformist agendas. Urban performance cultures were criticised, varieties of musician and dancer were persecuted, and 'in the vernacular press the prostitute became a yardstick to measure every manner of evil within contemporary society' ${ }^{\prime 107}$ However, the transition between Mughal and colonial cultural sensibilities was neither linear nor universal, and the anti-nautch movement needs to be viewed relative to the non-reformist, less radical factions of society, which continued to patronise the established arts of dancing girls and courtesans. A focus on language is one method of qualifying changes in this period: efforts to control or condemn women's speech, especially in its public or sung forms, need to be read alongside tazkiras that promoted and commemorated women poets and performers. The practice of imagining the city through its women was long-established in literary and musical circles, and was not immediately erased by colonialism.

Anita Anantharam reminds us that 'when women's bodies are displaced, ignored, or outright silenced...they are refigured back into the public body by various strategies; we need to look in different places to find these voices.' 108 Although the public presence of performing women and the poetic imaginary of their verses came under attack in this period, the ongoing circulation of these lyrics and biographies indicates the preservation of an emotional community invested in courtesan culture. As Rosenwein has noted, emotional communities are multiple and overlapping: the patrons and teachers of public women could operate in a colonial society with its own conventions and emotional styles, as well as participate in pre-existing Mughal social practices, with quite distinct emotional connotations.

Examining networks between multiple metropolitan bazaars and smaller satellite towns, and exchanges between male ustäds and female students, indicates the continuity of older aesthetic sensibilities, that were undaunted by the rhetoric of the new critics. Language defined the reputations of public women from different regions and repertoires, and their elevated speech was considered powerful and precious. Men who appreciated the language of courtesans prepared a modern literary space for them through print: a space in which some performing women were able to cultivate new forms of reputation and prestige and resist the challenges of colonial society.

\footnotetext{
107 Gupta, p. 115.

${ }^{108}$ A. Anantharam, Bodies that Remember: Women's Indigenous Knowledge and Cosmopolitanism in South Asian Poetry (Syracuse, 2012), p. 9.
} 